\title{
Foucault and the Practice of Educational Development: Power and Surveillance in Individual Consultations
}

\section{Peter Felten}

\section{Deandra Little}

\section{Allison Pingree}

Vanderbilt University

A common goal of educational development is to create a neutral, "safe" place for clients in individual consultations. Such an approach, while well intentioned, obscures the multifaceted web of power threading through and around our work. Using Michel Foucault's theories of sovereign and disciplinary power, we trace the forms that power can take in specific types of consultations (small group instructional diagnosis, course evaluations, and videotape). While power is always "dangerous," it is less likely to be damaging if we are conscious of its presence and impact-and of our oun participation in its complexiry.

Tn "Teaching Through Discussion as the Exercise of Disciplinary Power," Stephen Brookfield (2001) draws on French philosopher and social theorist Michel Foucault to analyze the circular and complex flow of power and surveillance that emerges in any pedagogical context. Brookficld shows that, paradoxically, even benign or democratically oriented teaching techniques can reiterate the very power structures they are designed to dismantle; seating people in a circle for discussion, for example, can unintentionally alienate those who choose not to participate. As a result, then, teachers can "often end up with an incomplete and naive understanding of how power manifests itself in college classrooms" (p. 262). 
Brookfield's analysis extends beyond instructors to educational developers. His advice seems particularly striking, given that such development work is so often framed as nonhierarchical, neutral, and safe (POD Network, 2002). In POD's guide for new faculty developers, Jenson (2002) explains that the consultant's role is "not to torture, but to nurture; not to disparage, but to encourage; not to command, but to coach; not to correct, but to suggest; not to clone but to hone" (p. 98). Brookfield (2001) concurs: "empowering teachers to be creative risk-takers is what we're about as faculty developers" (p. 261). However, Brookfield also suggests that developers should "recognize the presence of power in our daily practices, particularly the false face of apparently beneficent power exercised to help teachers or learners realize their full potential" (p. 262).

The purpose of this chapter is to look through a Foucauldian lens at possible false faces of apparently beneficent power in the context of individual consultations. By examining common types of consultations conducted by educational developers (small group instructional diagnosis, teaching evaluations, and videotape), we explore how power and surveillance shape individual work with clients. Our intention is not to offer definitive formulas or strategies for eliminating power in consultations. Instead, we contend that educational developers will become more reflective and capable practitioners when they have a clearer sense of what Brookfield (2001) calls the "unanticipated consequences of our supposedly empowering practices" (p. 262)-particularly as these emerge in our individual consultation work.

\section{Michel Foucault, French Social Theorist}

In Discipline and Punish: The Birth of the Prison (1995), Foucault examines mechanisms of power at work in social and state institutions, particularly as these shifted from sovereign power exercised by kings over their kingdoms to disciplinary power exercised over and between subjects within the social body of city-states. Foucault's definitions of sovereign and disciplinary power are pertinent for our examination of power and surveillance in individual consultations because they explain the relationship between power and the production of knowledge as reciprocal-even within a seemingly democratic or safe environment like educational consulting. As Foucault (1980a) insists, " $[t]$ he exercise of power perpetually creates knowledge and conversely, knowledge constantly induces effects of power" (p. 52).

Foucault defines sovereign power as power that operates unidirectionally and hicrarchically. In a system of sovereign power, the source of power is visible and acts intermittently to punish, reward, or respond to a specific set of 
circumstances, as in times of war or crisis. This type of power emanates from particular, identifiable individuals (e.g., the king or sovereign) or is administered by visible agents acting on behalf of these individuals. Within the classroom, instructors hold some degree of sovereign power; they are visible and identifiable representatives of power for their students and exercise power intermittently over students' lives through assignments and grading.

Although sovereign power is often exercised in visible, rigid, and established patterns in traditional university hierarchies, disciplinary power is at work as well. Unlike sovereign power, disciplinary power is not centralized in a perceivable source; there is no one person establishing and enforcing the rules that govern and socialize. Instead, this power is all-pervasive and embedded within the everyday lives and actions of individuals. "Employed and exercised through a net-like organization". (Foucault, 1980b, p. 98), disciplinary power operates as a web of power relations threaded between and among individuals and groups. As exercised through this multidirectional net, disciplinary power becomes an essentially corrective force fostering normalization and conformity. It operates through, and in turn constitutes, the processes by which we discipline ourselves to conform to an imagined ideal or norm.

The primary purpose of disciplinary power is to train subjects to fit the norms of a specific discipline. Through disciplinary modes such as surveillance and the examination, Foucault suggests that certain qualities, skills, and social behaviors are measured against the norm, leading to censure or reward. We contend that the assessment and consultation models employed in educational development are examples of such norming processes. In effect, these rituals, as examinations, produce " $a$ normalizing gaze, a surveillance that makes it possible to qualify, to classify and to punish [and that] establishes over individuals a visibility through which one differentiates them and judges them" (Foucault, 1995, p. 184).

Disciplinary power, then, is exercised invisibly through instruments of surveillance over subjects who are aware they are being surveyed. As Foucault (1995) insists, "It is the fact of being constantly seen, of being able always to be seen, that maintains the disciplined individual in his subjection" (p. 187). Or, as Brookfield (2001) further explains,

in a society subject to disciplinary power, we discipline ourselves by watching others and ourselves... we watch ourselves because we sense that our attempt to stay close to the norm is itself being watched by another, all-secing, presence. We carry within us the sense that "out there," in some hidden undiscoverable location, "they" are constantly observing us. (p. 268) 
Being a subject within a disciplinary society such as the university means having a heightened awareness of being observed, assessed, and judged by others; indeed, a well-defined relation of surveillance is, for Foucault (1995), "inscribed at the heart of the practice of teaching" (p. 176).

To what extent might surveillance be "inscribed," as well, at the "heart of the practice" of teaching the teachers-at the heart of educational development? That is, how do both sovereign and disciplinary power affect not only classroom instructors but also the developers who consult with them? Are there "false faces of apparently beneficent power" involved in educational consultations-and if so, what do they look like? Do they differ depending on the nature of the teaching data (videotape, student course evaluations, etc.) that underlies the consultation?

Such questions might be uncomfortable for us as developers, since we often try to work as counterpoints to the barriers that sovereign power creates in our institutions. But in swerving away from such questions, we may fail to recognize how and where we nonetheless operate within, and even perpetuate, a web of disciplinary power-and in that blindness, potentially exacerbate the very power dynamics we work to mitigate.

In order to clarify how such "false faces" of beneficence and "unanticipated consequences" of power might emerge, and how awareness of them can increase (instead of inhibit) developers' capabilities, we will now consider how both sovereign and disciplinary power circulate through the creation of common forms of teaching data, and through the individual consultations emerging from them: consultations on small group instructional diagnoses (SGIDs), on student course evaluations, and on videotapes.

\section{Small Group Instructional Diagnosis Consultations}

Typically facilitated around midterm, the SGID provides feedback within a given semester, thus promoting dialogue and the clarification of student and instructor expectations and allowing for timely corrective action in the classroom. As explained by Clark and Redmond (1982), the SGID was purposefully designed to elicit feedback, not evaluation: "the very word 'evaluation' connotes a judgment of goodness or badness. We learned not to call SGID evaluation but rather to label it a feedback process" (p. 4). Because the SGID is intended to function as a formative rather than a summative or evaluative instrument, it has become a multi-purpose tool at some institutions, where it is used to provide feedback to individual faculty, to inform coordinators of multisectioned courses or of TA training on the effectiveness of their overall 
course or program, and to assess the efficacy of classroom or curriculum design (Black, 1998).

The SGID, though designed for assessment purposes, does reveal an evaluative overlay when we consider the way that disciplinary power works through it. Inherent in the SGID is the idea that comparing student feedback with instructor goals will help diagnose problem areas in classroom instruction, allowing the instructor to enhance his or her teaching, to clarify the purpose of the course, and to assist student learning. In other words, educational developers (and teachers requesting an SGID) often hold the assumption that an SGID will give an instructor useful information that may potentially improve his or her teaching. Foucauldian analysis, however, raises the question of whether the SGID process produces "better" teaching or simply "more normal" teaching.

Even granting that the SGID process reinforces positive behaviors and can potentially correct ineffective behaviors, it also allows students to discipline or compel instructors to fit the assumed norms of good teaching. Although student remarks have the power to shape the course only as the instructor permits, their remarks still function as form of social control. For the instructors, the SGID serves as an examination-a test Foucault (1995) describes as "a normalizing gaze" (p. 184) through which they are made aware of being watched and judged by their students. Moreover, the feedback process confirms that the instructors, in their attempts to meet the norm, are aware of "being watched by another, all-seeing, presence" (Brookfield, 2001, p. 268).

The open-ended questions used in the SGID process mean that this examination introduces less explicit norms than teaching evaluations do, thus requiring students to bring their own norms into the process. The SGID surfaces individualized assumptions about teaching because it permits, and even encourages, students to scrutinize their instructors with a "normalizing judgment" by measuring them against their own unspoken understandings of how a "professor" or "teaching assistant" should and does behave. The diagnosis emphasizes the importance of watching and reporting on how well or poorly the class, and by extension, the instructor, fit the norms of instruction that students have internalized. Concerns about standards of normalization or judgment are often apparent in students' remarks on the efficacy of the curriculum, pedagogical methods, or fairness of grading standards. Even such commonplace student comments as "she assigns too much reading" and "his tests are too hard" imply a norm. In effect, the SGID functions as one of the processes by which professors and teaching assistants discipline themselves to conform 
to an imagined ideal, a norm acknowledged (if not clearly defined) by students, faculty, and administration alike.

Given the cloak of anonymity and the voice of consensus through the structure of the SGID, students are able to evaluate the instructors and the course without fear of punishment or anticipation of individual rewards. Because it grants the students an outlet for expression, the SGID disrupts the hierarchical power structure of a traditional classroom. If couched in terms of sovereign power, the SGID allows a measure of resistance; it gives the "common people" a voice and encourages them to speak in favor of or against the "ruler." The common SGID technique of gathering a wide range of student perspectives, rather than insisting on a consensus of opinion-which Clark and Redmond originally conceived as "a critical part of the SGID process" (Diamond, 2002, p. 85) —creates a more democratic environment and allows for more student voices to be heard and acknowledged. Yet this instrument, however inclusive, heightens both the students' and instructors' awareness of being surveyed or being coerced through evaluative observation. In this way, the SGID reinforces the implicit understanding that disciplinary power is exercised through surveillance.

At first glance, educational developers seem separate from the power dynamic operating in the SGID. As outside observers, they simply record and report the students' comments. However, even if they act according to common practices for consultations, taking "non-judgmental, objective observational notes [or giving] feedback in a non-threatening, non-directive manner" (Black, 1998, p. 246), consultants are still enmeshed within a web of disciplinary power. Accordingly, reexamining the SGID process from the Foucauldian perspective forces us to face a separate but related set of normsthose involved in gathering the data for and presenting it during the individual consultation. Although developers do not judge instructors per se, through the SGID process, they do survey and examine them. The developers are responsible for administering the instrument-the means by which "normal" and effective teaching is measured and defined-for gathering the data, and for recording and interpreting it for the instructor. Whether or not developers invoke their own knowledge of teaching as authoritative during the consultation, that is, whether or not their individual approaches to consultation are collaborative, confrontational, or prescriptive- to name but a few models of client-developer interaction (Brinko, 1997)-they are the assumed experts and thus wield disciplinary power during the consultation, both because they represent the students' voices through the feedback process and because they represent a larger ideal of best practices for teaching excellence. 
The educational developer's voice in this process is often overlooked, but it is crucial to recognize that this voice shapes how information is gathered and recorded and how it wields disciplinary power through the SGID. Through this instrument, the consultant brings his or her own teaching norms to bear in a number of ways, from deciding which points to clarify in the student discussion to selecting which comments to include or emphasize in the report, and even to choosing whether or not to share research on established norms for effective teaching during the follow up consultation. Although naming this power does not make it disappear from SGID consultations, as we might hope, recognizing it does allow us to respond to it consciously and reflectively. The alternative-failing to acknowledge this subtle but dangerous web of powermeans compromising the core values educational developers hold dear.

\section{Student Course Evaluation Consultations}

The SGID typically occurs only at the instructor's request. Student ratings, on the other hand, have become a nearly universal requirement for faculty and teaching assistants. Student course evaluations remain the primary, often the only, systematic source of data used to evaluate teaching at many colleges and universities in the United States (Cashin, 1999). Even when students and institutions use course evaluations responsibly, faculty may experience the process as intrusive, frustrating, and frightening (Ory, 2001). Course evaluations in many ways replicate Foucault's concept of a "panoptic prison" where, as McDonough (1993) describes it, inmates "are constantly aware that their behavior is subject to surveillance and observation. However, they are also unaware of when and how this surveillance occurs" ( 9 7). Faculty know that and when students will fill out the evaluations, but not when or bow students will form their judgments. Faculty likewise do not often know when and how their evaluations will be interpreted by the sovereign powers at the university (i.e., department chairs, deans, tenure and promotion committees, and so on).

Course cvaluations thus offer an institutionally sanctioned way for students to exert disciplinary power over faculty by judging faculty against both the rating's explicit and the student's implicit norms of good teaching. Like the SGID, the evaluation process typically provides students with anonymity, permitting them to report without consequence on their surveillance and judgments of faculty. The power students exert is complicated by the ambiguity common in student feedback. Narrative comments often contradict each other and can include deeply personal praise or criticism of a teacher. Since faculty (and others reading the evaluations) cannot probe for clarification from the students, the written comments can be difficult to understand 
(Lewis, 2001). Quantitative scores may be no better, despite the precise numbers in the data. Franklin (2001) highlights a mistaken "tendency to view numbers as more objective and possibly less subject to dispute than more qualitative approaches" (p. 88).

Just as the disciplinary power inherent in course evaluations is ambiguous, so too is the sovereign power exerted through the institutional use of evaluations. Student ratings are connected to the institution's sovereign power to appoint or deny reappointment to faculty and teaching assistants. Even if explicit policies exist about when and how evaluations are to be used in personnel decisions, the contradictions and uncertainty inherent in student ratings create difficultly for decision-makers. Seldin (1999) notes a "growing chorus of complaints from those who serve on tenure and promotion committees that they are given little solid information about classroom teaching performance" (p. 22). This contributes to what Theall and Franklin (2001) call "major problems in day-to-day practice" of making sense of even technically rigorous evaluations: "student ratings are often misinterpreted, misused, and not accompanied by other information that allows users to make sound decisions" (p. 46).

Faced with so much uncertainty, some faculty and TAs turn to consultants at their university's teaching center (Knapper \& Piccinin, 1999). Many such centers emphasize their separation from their school's formal system of judging and evaluating faculty-and in so doing, place themselves outside the visible hierarchy of sovereign power. However, such centers are not outside the ring of disciplinary power, even if they have strict confidentiality policies, since such policies only separate educational developers from sovereign power. Disciplinary power, by contrast, is impossible to avoid. Indeed, a client's motivation for mecting a consultant may stem from the client's perceptions of the consultant's disciplinary power-power rooted in the consultant's expertise in interpreting student ratings and understanding of campus policies and practices about course evaluations.

These perceptions empower the consultant, even if he or she does not recognize it. As with an SGID consultation, the developer's choices about whether and how to respond to a client's situation represent, in effect, an exercise of disciplinary power. In a consultation with a tenure-track faculty member concerned about her teaching evaluations, for example, one developer might recommend safe but limited techniques in an effort to bump up the scores of a traditional lecturer, thus privileging the client's need to build a solid tenure filc over the students' need for an optimal learning environment; another developer in that same consultation might suggest more radical 
changes to promote active learning, thereby enhancing student learning despite the likely short-term decline in student ratings (Franklin, 2001). The developer, by necessity, makes choices during a consultation, and those choices are an exercise of disciplinary power over the client. A consultant may strive to create a safe and nurturing environment for the conversations about student course evaluations, but disciplinary power cannot be removed from the room.

\section{Videotape Consultations}

Of all the modes of educational development consultation, the videotape presents conditions that could seem most Foucauldian of all: The omnipresent eye of the camera monitors the teacher's every move. Surveillance-the fact of being constantly seen-is rendered utterly explicit. Part of the power of this medium in educational development is that, unlike SGIDs or student evaluations, teachers constantly encounter the medium itself in their everyday lives: It is nearly impossible to avoid video-based representations of human experience at all levels of culture, from television to home videos to security cameras monitoring shoppers. Because filmic representations are so culturally pervasive, then, videotapes of teaching have a particularly strong weight attached to them, even before the consultation begins.

How a vidcotape of teaching is made is freighted with acts of interpretation and thus disciplinary power as well. Decisions about when and how to focus on students or the teacher, when and how to zoom in or out, or what camera angles to use are just a few examples of ways the creation of a videotape can shape the disciplinary power dynamics in the data itself. An additional layer, in a higher education setting, is the use that sovereign powers make of teaching videotapes. That is, videos are created and analyzed not only for formative purposes, but also increasingly for summative purposes in tenure, promotion, or review portfolios. As such, the data in a videotape can incite some of the same power dynamics and high stakes as those connected with student course evaluations.

An educational videotape consultation, then, can present a highly overdetermined power disequilibrium between consultant and client. Indeed, given clients' familiarity with and reliance on videotape in popular cultural experience, the videotape may seem to offer a more straightforward or objective transcription of one's teaching (versus having to "interpret" written text) and thereby more easily capture what is "really" going on in the classroom. Such confidence in the truth and importance of visual data may lead a client to certain assumptions about the consultant's role-for example, that the consultant can see the "reality" of a classroom situation most clearly and tell the client 
what to do to "fix" it, or that the consultant might watch the videotape as a mode of examination in order to "grade" the teaching. In these modes, clients imbue consultants with both disciplinary and sovereign forms of power.

Educational developers have created a variety of ways to navigate within this highly charged medium of teaching data. Taylor-Way (1988) suggests a structured and reflective approach for videotape consultations. Often, videotape consultations are framed as a shared conversation between teachers, with the remote control in the hands of the client and with the implied message of "this is your consultation, not mine." Lewis (2002) recommends being aware of, and know how to distinguish among, the many hats that consultants (in general) can wear: data collector, data manager, facilitator, support system, counselor, information source.

Whatever the consultational framework, though, educational consultants typically try to disavow positions of power, steering away from the notions of telling clients what to do-and videotape consultations are no exception. For example, Knapper and Piccinin (1999) conclude that many developers believe in a "value-free approach to consultation, perhaps equivalent to client-centered therapy, in which the teacher's goals are preeminent, instructional problems are defined by the person seeking advice, and strategies are selected accordingly, even if the consultant has private doubts about them" (p. 5). Hicks (1999) reiterates this point, claiming that "the literature on instructional consultation almost always assumes that the power to set the agenda will lie with the academic seeking advice and assistance" (p. 14).

In our attempts to let the client shape the consultation agenda, however, developers can sometimes pursue an illusion: that such a transaction is valuefree, neutral, unimpeded, or not substantially shaped by power dynamics. By contrast, important gains can come from consultants being more explicit and conscious about our own power positions, and about our own assumptions about other factors shaping the consultation, such as the nature of authority, knowledge, and expertise.

In other words, even as we often move to establish a horizontal equilibrium of shared power, consultants paradoxically may push power further out of equilibrium. This is because in assuming a power- and value-free environment, consultants may instead unknowingly insert their own assumptions about what should be the nature, focus, and purpose of the consultation-all without taking the time to be explicit about their views or to understand their clients' perspectives on those same issues. As Knapper and Piccinin (1999) assert, educational developers need to "spell out the conceptual basis for their work, dealing both with the consulting strategies they use to identify problems 
and effect change and with the conceptions of teaching that underpin the advice they offer" (pp. 5-6). As Jenson (2002) recommends, "know the limits of your position," "prepare to work with each client and each situation individually," and "be aware of the client's expectations in conferring with you" (pp. 92-94).

\section{Power and Danger in Consultations}

As is evident in all of these analyses, danger and risk emerge in educational consultations in a variety of ways. Evaluative teaching data can threaten faculty and teaching assistants' careers. Consultants can potentially wield considerable power over clients' perceptions of their student ratings and feedback and of themselves as teachers - this power can also extend to clients' careers. Consultations are also dangerous for developers. Our credibility as colleagues with useful expertise and resources is at stake, and in times of budget curs and scarce resources, such credibility may seem particularly important to uphold.

The danger involved in power relations extends to those outside the consultation room, too. The students (current and future) of clients who voice their views are vicariously present during consultations and stand to be affected by them. Similarly, clients' attitudes toward their institutions potentially are at stake, endangering the university's sovereign powers. Department chairs and others excrcising sovereign power at the university are not in jeopardy of losing their institutional power, but their disciplinary power may be reduced (or expanded) depending on clients' reaction to the consultation experience. In short, the nature of disciplinary power makes individual consultations a dangerous encounter for all involved.

\section{Possible Responses for Educational Developers}

Given this complex and dangerous web of power layers-the many ways in which what we intend as democratic moves may in fact reiterate the power structures we are trying to counteract-educational developers may wonder what kinds of responses, if any, may be useful to themselves and their clients. Foucault (1983) urges us to face such dangers squarely: "If everything is dangerous, then we always have something to do" (p. 231). In the presence of such danger, then, what should educational developers do? More specifically, in what ways can an awareness of the "unanticipated consequences of our supposedly empowering practices" actually lead to more effective practice? What are possible roles for the consultant in noticing, reinforcing, reflecting on, and 
resisting power (and the norms that underlie it)? The following are some approaches that may begin to answer these questions.

\section{Power Is Dangerous, but Not Necessarily Bad}

The presence of power is not necessarily bad. Indeed, as Foucault (1983) insists: "My point is not that everything is bad, but that everything is dangerous, which is not exactly the same as bad" (pp. 231-232). Thus, to recognize the ways in which various assessment instruments function as examinations or as instruments by which teaching is normalized is not to label them as necessarily problematic. It does, however, acknowledge not only the layers of power involved in the data itself, but also our own positions of power in collecting the data and bringing our expertise into consultations. It also recognizes that we, as educational developers, have a voice in this process, not only as student comments are gathered and reported back to the instructor but also as we choose to frame problems and recommend pedagogical changes to clients.

\section{Educational Developers Can Use Their Powers to Reflect and Reinforce}

As educational developers, we can use the kinds of power we have: power in our roles as expert resources on teaching assessment processes; power in our awareness of how sovereign and disciplinary power may be operating at our institutions; and power as the facilitators of communication in potentially charged consultations where language and tone have important consequences, and where safety and confidentiality can be used either as positive forces or as causes of shame and isolation.

\section{Educational Development as Resistance}

Ultimately, such practices and awareness can form a kind of resistance, leading to what Foucault calls an ethic of care. As McDonough (1993) asserts, "Caring relations for Foucault... must constantly be open to critical scrutiny... in order to criticize something effectively, we must care deeply about something else" ( 11 ). Because we care decply about teaching and learning, educational developers are compelled to act. The dangers presented by power and surveillance should not limit us. Instead, as philosopher and cultural critic Susan Bordo (1997) insists, since "[c]ertain and conclusive knowledge of the effectiveness of our actions... is not available to us, [we should assess] the chief dangers or needs of a situation-the practices that require demystification, criticism, transformation-and we act" (p. 191). It is our responsibility and opportunity to resist the many forms that power can take: to identify and discuss the disciplinary power of client perceptions about evaluations; to educate 
sovereign decision-makers about best practices in using ratings; to help students think explicitly about the norming power of their assessments of instructors; and to reflect together as educational developers about how power is at the core of our work, despite our attempts to avoid it.

In the end, even though elements of surveillance and power permeate our work as consultants, an awareness of these dynamics-and of the "unanticipated consequences" that stem from them-can lead to deeper reflection and thus to a form of resistance that offers some amount of hope and care. As Foucault (1983) asserts, "my position leads not to apathy but to a hyper- and pessimistic activism" (p. 232). McDonough (1993) adds that "the incitement to care has the panoptic effect of creating individuals who are increasingly willing, even eager, to make themselves visible, open to scrutiny" ( 910 ). By modeling such processes of self-scrutiny, we as educational developers may begin to recognize the forms of unacknowledged power we exert, beneficent though they seem. Making our own power visible is the first step in actively resisting it, as we, as well as our clients, navigate the compelling and intense power relations that comprise institutions of higher education.

\section{Note}

If you are interested in thinking more concretely about these issues, please visit our web site for case studies and reflection questions on power in SGID, teaching evaluation, and videotape consultations: http://www.vanderbilt.edu/ $\mathrm{cft} /$ resources/gleanings/casestudies.htm

\section{REFERENCES}

Black, B. (1998). Using the SGID method for a variety of purposes. In M. Kaplan \& D. Lieberman (Eds.), To improve the academy: Vol. 17. Resources for faculty, instructional, and organizational development (pp. 245-262). Stillwater, OK: New Forums Press.

Bordo, S. (1997). Twilight zones: The bidden life of cultural images from Plato to O.J. Berkeley, CA: California University Press.

Brinko, K. (1997). The interactions of teaching improvement. In K. T. Brinko \& R. J. Menges (Eds.), Practically speaking: A sourcebook for instructional consultants in higher education (pp. 3-8). Stillwater, OK: New Forums Press.

Brookficld, S. D. (2001). Teaching through discussion as the exercise of disciplinary power. In D. Lieberman \& C. Wehlburg (Eds.), To improve she academy: Vol. 20. Resources for faculin, instructional, and organizational development (pp. 260-273). Bolton, MA: Anker. 
Cashin, W. E. (1999). Student ratings of teaching: Uses and misuses. In P. Seldin \& Associates, Changing practices in evaluating teaching: A practical guide to improved faculty performance and promotion/tenure decisions (pp. 25-44). Bolton, MA: Anker.

Clark, D., \& Redmond, M. (1982). Small group instructional diagnosis: Final report. Washington, DC: Fund for the Improvement of Postsecondary Education. (ERIC Document Reproduction Service No. ED217954)

Diamond, N. A. (2002). Small group instructional diagnosis: Tapping student perceptions of teaching. In K. H. Gillespie (Ed.), A guide to faculty development: Practical advice, examples, and resources (pp. 82-91). Bolton, MA: Anker.

Foucault, M. (1980a). Prison talk. In C. Gordon (Ed. \& Trans.), Power/knowledge: Selected interviews and other writings, 1972-1977 (pp. 37-54). New York, NY: Bentham.

Foucault, M. (1980b). Two lectures. In C. Gordon (Ed. \& Trans.), Power/knowledge: Selected interviews and other writings, 1972-1977 (pp. 78-108). New York, NY: Bentham.

Foucault, M. (1983). On the genealogy of ethics. In H. L Dreyfus \& P. Rabinow (Eds.), Michel Foucault: Beyond structuralism and hermeneutics (pp. 231-232). Chicago, IL: The University of Chicago Press.

Foucault, M. (1995). Discipline and punish: The birth of the prison (A. Sheridan, Trans.). New York, NY: Vintage Books. (Original work published 1977).

Franklin, J. (2001). Interpreting the numbers: Using a narrative to help others read student evaluations of your teaching accurately. In K. G. Lewis (Ed.), Techniques and strategies for interpreting student evaluations (pp. 85-100). New Directions for Teaching and Learning, No. 87. San Francisco, CA: Jossey-Bass.

Hicks, O. (1999). A conceptual framework for instructional consultation. In C. Knapper \& S. Piccinin (Eds.), Using consultants to improve teaching (pp. 9-18). New Directions for Teaching and Learning. No. 79. San Francisco, CA: JosseyBass.

Jenson, J. D. (2002). If I knew then what I know now: A first-year faculty consultant's top ten list. In K. H. Gillespie (Fd.), A guide to faculty development: Practical advice, examples, and resources (pp. 92-98). Bolton, MA: Anker.

Knapper, C., \& Piccinin, S. (1999). Consulting about teaching: An overview. In C. Knapper \& S. Piccinin (Eds.), Using consultants to improve teaching (pp. 3-7). New Directions for Teaching and Learning, No. 79. San Francisco, CA: JosscyBass. 
Lewis, K. G. (2001). Making sense of student written comments. In K. G. Lewis (Ed.), Techniques and strategies for interpreting student evaluations (pp. 25-32). New Directions for Teaching and Learning, No. 87. San Francisco, CA: JosseyBass.

Lewis, K. G. (2002). The process of individual consultation. In K. H. Gillespie (Ed.), A guide to faculty development: Practical advice, examples, and resources (pp. 59-73). Bolton, MA: Anker.

McDonough, K. (1993). Overcoming ambivalence about Foucault's relevance for education. Retrieved March 23, 2003, from http://www.ed.uiuc.edu/eps/pes-year book/93_docs/mcdonoug.hem

Ory, J. C. (2001). Faculty thoughts and concerns about student ratings. In K. G. Lewis (Ed.), Techniques and strategies for interpreting student evaluations (pp. 3-15). New Directions for Teaching and Learning, No. 87. San Francisco, CA: Jossey-Bass.

POD Nerwork. (2002). Ethical guidelines for educational developers. Retrieved March 23, 2003, from http://www.podnetwork.org/development/ethicalguidelines.htm

Seldin, P. (1999). Current practices-good and bad—nationally. In P. Seldin \& Associates, Changing practices in evaluating teaching: A practical guide to improved faculty performance and promotion/tenure decisions (pp. 1-24). Bolton, MA: Anker.

Taylor-Way, D. (1988). Consultation with video: Memory management through stimulated recall. In K. G. Lewis (Ed.), Face to face: A sourcebook of individual consultation tecloniques for faculty/instructional developers (pp. 159-191). Stillwater, OK: New Forums Press.

Theall, M., \& Franklin, J. (2001). Looking for bias in all the wrong places: A search for truth or a witch hunt in student ratings of instruction? In $M$. Theall, P. C. Abrami, \& L. A. Mets (Eds.), The student ratings debate: Are they valid? How can we best use them? (pp. 45-56). New Directions for Institutional Research, No. 109. San Francisco, CA: Jossey-Bass. 
Contact:

Peter Felten

Vanderbilt University

Center for Teaching

Box 351537

Nashville, TN 37235

Voice (615) 322-7290

Fax (615) 343-8111

Email peter.felten@vanderbilt.edu

Deandra Little

Vanderbilt University

English Department

Box 351654

Nashville, TN 37235

Voice (615) 322-2541

Fax (615) 343-8028

Email deandra.j.little@vanderbilt.edu

Allison Pingree

Vanderbilt University

Center for Teaching

Box 351537

Nashville, TN 37235

Phone (615) 322-7290

Fax (615) 343-8111

Email Allison.pingree@vanderbilt.edu

Peter Felten is Assistant Director of the Vanderbilt University Center for Teaching, and he teaches courses in history and American and sourhern studies. His current research explores how emotion shapes learning in service-learning courses, and how teaching and learning in history are changed by the use of visual in addition to textual sources.

Deandra Little is a full-time lecturer in the English Department at Vanderbilt University and teaches courses in English and women's studies. Her current research interests include the ethics and efficacy of reimagining the classroom as a site for community-building, both within courses using social software and as a bridging between course and the larger community through service learning.

Allison Pingree is Director of the Vanderbilt University Center for Teaching, and teaches courses in English, American and southern studies, and women's studies. Her current research interests include cmotion in the classroom, one-on-one teaching and mentoring, and leadership and organizational change. 